\section{First record of Thelyphonus sepiaris (Butler 1873) (Uropygi: Thelyphonidae) from Andhra Pradesh, India}

\section{S.M. Maqsood Javed ${ }^{1}$, K. Thulsi Rao ${ }^{2}$, Farida Tampal ${ }^{3}$ \& C. Srinivasulu ${ }^{4}$}

${ }^{1,3}$ World Wide Fund for Nature-India (WWF), APSO, Ho. No. 818, Castle Hills, Road No. 2, Near NMDC, Vijayanagar Colony, Hyderabad 500057, Andhra Pradesh, India

2 Eco-Research and Monitoring Laboratories, Nagarjunasagar Srisailam Tiger Reserve, Sundipenta, Kurnool District, Andhra Pradesh 518102, India

${ }^{4}$ Wildlife Biology Section, Department of Zoology, University College of Science, Osmania University, Hyderabad, Andhra Pradesh 500007, India

Email: ${ }^{1}$ javedwwf2007@gmail.com

Whip-scorpions are recognized globally by 103 species under 16 genera (Harvey 2002, 2003) and from the Indian subcontinent by 19 species in six genera (Pocock 1900). Uropygids are imposing, robust tropical predators with enlarged raptorial pedipalps and a multi-segmented elongated post-pygidium. Like schizomids, they possess anal glands that they use to spray a chemical to deter predators (Eisner et al. 1961). Detailed systematic work on this neglected group was carried out by Rowland \& Cooke (1973) and Harvey (2002).

The Whip-scorpion Thelyphonus sepiaris (Butler 1873) is being recorded for the first time from different localities in Andhra Pradesh during the preparation of current Arachnid faunal inventory. The present communication deals with the

Date of online publication 26 July 2009

ISSN 0974-7907 (online) | 0974-7893 (print)

Editor: Vinod Khanna

\section{Manuscript details:}

Ms \# 02088

Received 23 October 2008

Final received 11 July 2009

Finally accepted 14 July 2009

Citation: Javed, S.M.M., K.T. Rao, F. Tampal \& C. Srinivasulu (2009). First record of Thelyphonus sepiaris (Butler 1873) (Uropygi: Thelyphonidae) from Andhra Pradesh, India. Journal of Threatened Taxa 1(7): 395-397.

Copyright: @ S.M. Maqsood Javed, K. Thulsi Rao, Farida Tampal \& C. Srinivasulu 2009. Creative Commons Attribution 3.0 Unported License. JoTT allows unrestricted use of this article in any medium for non-profit purposes, reproduction and distribution by providing adequate credit to the authors and the source of publication.

Acknowledgement: The authors are very much thankful to Sri K.S. Rao, IFS, Prl. Chief Conservator of Forests, Sri Hitesh Malhotra, IFS, Prl. Chie Conservator of Forest (Wildlife) and Chief Wildlife Warden, Sri Sunil Kumar, IFS, Addl. Prl. Chief Conservator of Forest (Wildlife) and Sri A.K. Nayak, IFS, Conservator of Forests \& Field Director, Nagarjunasagar Srisailam Tiger Reserve for constant encouragement and sustained support. We are also grateful to $\mathrm{Dr}$. Rajesh Gopal, IFS, Inspector General of Forests, Ministry of Environment and Forests for funding support and encouragements. SMMJ \& FT expresses gratitude to Sri Anil Kumar V. Epur, Chairman, WWF-AP State Committee, Sri Ravi Singh, Secretary General \& CEO, WWF-India, New Delhi for constant support and encouragement. CS acknowledges CSIR, New Delhi for funding and Head Department of Zoology, Osmania University, Hyderabad for encouragement. We are very much thankful to Dr. D.B. Bastawade, Senior Scientist (Retd.), ZSI, WRS, Pune, Maharashtra for Identifying and providing references and other valuable information.

OPEN AGGESS | FREE DOWNLOAD new and known distribution and a short description for Thelyphonus sepiaris (Butler 1873 ).

Material examined: Three adult males of the Whip-scorpion Thelyphonus sepiaris (Butler 1873) were sighted and studied from three different localities in Andhra Pradesh. An adult male Whip-scorpion (Image 2) was captured on 9 May 2005, from the Damarla Kunta (155'ㅇ \& $\left.78^{\circ} 48^{\prime} \mathrm{E}\right)$ near Peddacheruvu, Nagarjunasagar-Srisailam Tiger Reserve, Kurnool district, Andhra Pradesh (Image 1) by KTR \& SMMJ and preserved in $70 \%$ alcohol. The identified material has been deposited in the Andhra Pradesh Forest Department's Field Museum of Ecological Research and Monitoring Laboratories, Sundipenta, Kurnool District. Subsequently, a male specimen was sighted by CS from Godavari River basin on 30 June 2006 near Tadwai (Image 1), Eturnagaram Wildlife Sanctuary, Warangal District and another male was sighted on 12 February 2007, near Perantalapally Temple $\left(17^{\circ} 27^{\prime} \mathrm{N} \& 81^{\circ} 26^{\prime} \mathrm{E}\right.$, $48.5 \mathrm{~m}$ above msl) (Image 1) by FT \& SMMJ on the right bank of river Godavari in the Papikonda Hills of northern Eastern Ghats, Khammam District.

Both these specimens were found under decaying logs near a water body. The later specimens sighted and studied were not collected for the want of collection permits.

\section{Discription}

Male (ERMLABS-ARAU-1): Colour blackish brown above and on chelae, reddish brown below. Legs black with the tibiae and tarsi deep red-brown. Carapace and terga are coarsely rugose, with close-set punctures and granules. A smooth paler median line is present on 2 and 3 and just traceable on posterior terga. Distinct ocular keel or ridge extends along the margin of the carapace between the median and lateral eyes of each side (Image 3). First abdominal sternum is shining, sparsely punctured and striate, granular marginally; the rest coarsely rugose with deep median groove. Second segment have a median tooth like spine (Image 8). Last segment of abdomen (anal segment) is with two ommatoids, without a dark sclerotized spot near the center (Image 7). Pedipalp/Chelae: maxillary process of coxa internally shouldered with one strong and short tooth (Image 5). Femur and tibia is granular below, polished and punctured above. Trochanter is granular above, armed below with 2 teeth and with 6 above (Image 4). Femur with two small tubercles above and one below. Patella of male consists of an unmodified apophysis (Image 6). Tibial apophysis armed in front with 6 teeth and behind with about 3 . Hand thicker than tibia, its inner edge denticulate, granular internally; movable finger with anguliform sub apical tooth. Legs of $2^{\text {nd }}, 3^{\text {rd }}$, and $4^{\text {th }}$ pairs possess tibial spine. Caudal flagellum hairy and possess 33 segments.

Measurements (in mm) (ERMLABS-ARAU-1): Total body length (excluding chelicerae and caudal flagellum) 35.00. Carapace, median length 13.00, median width 8.50. Abdomen length (including anal segments) 22.00, width 10.50. Pedipalps: trochanter length 4.00, width 4.50; femur length 4.00, width 3.00; patella length 3.50, width 3.50; tibia length 5.50, width 4.00; tarsus claw length 4.00. Leg I: femur length 8.00, patella length 5.00, tibia length 9.50, tarsus length 7.50. Leg II: femur length 6.50 , patella length 5.00 , tibia length 8.50 , tarsus 


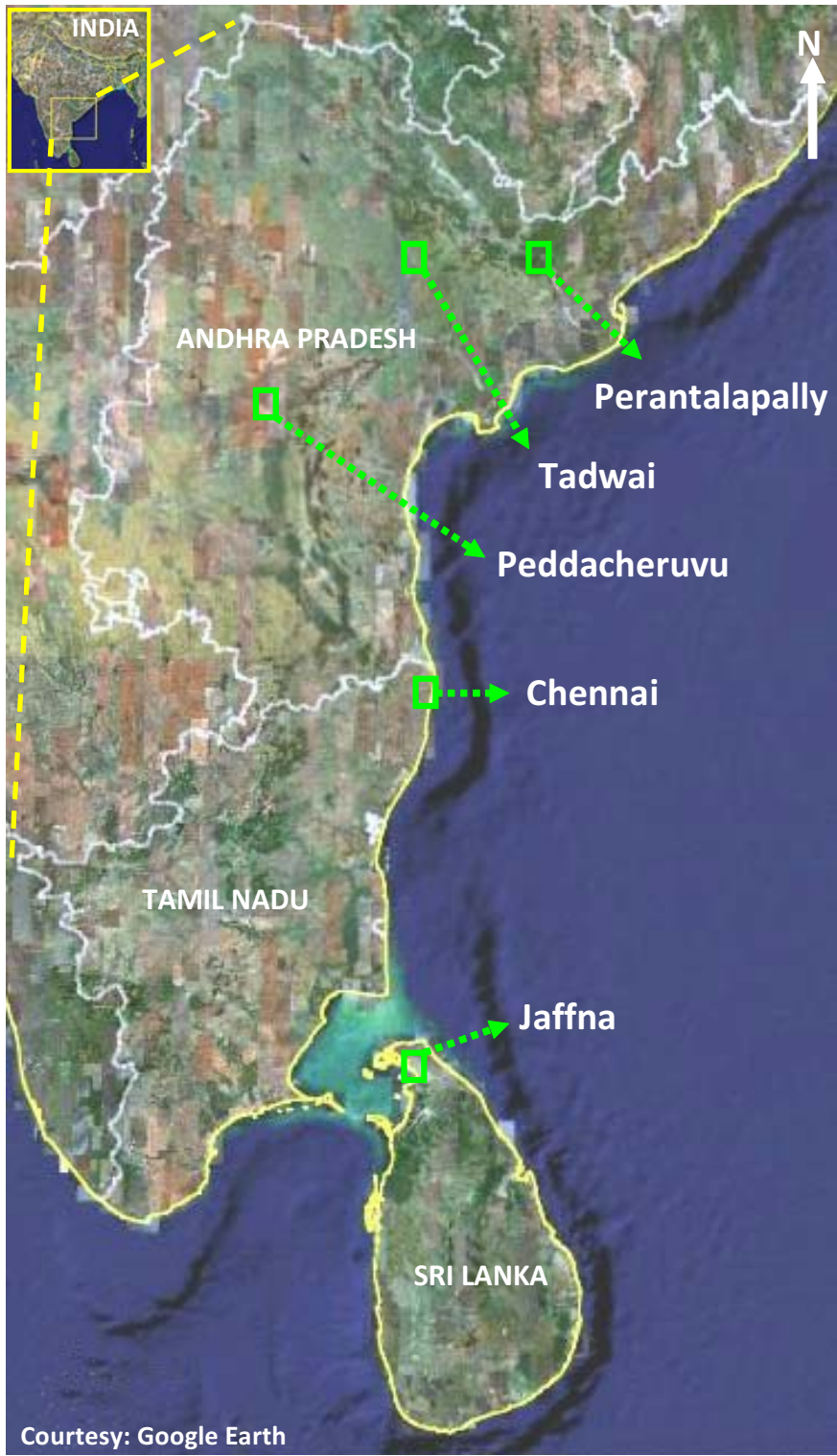

Image 1. Satellite image showing map (not to scale) depicting three distribution sites of whip-scorpion Thelyphonus sepiaris (Butler 1873) in the Eastern Ghats of Andhra Pradesh, India

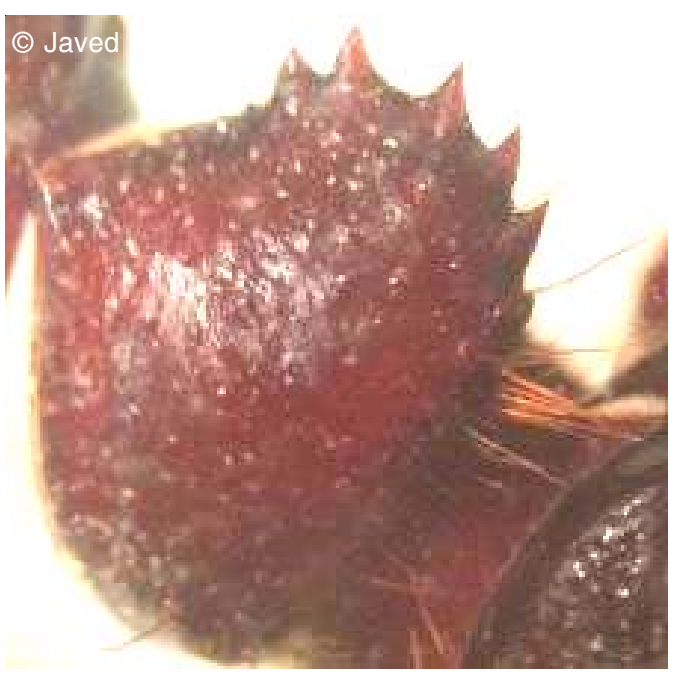

Image 4. Dorsal view of left trochanter of pedipalp

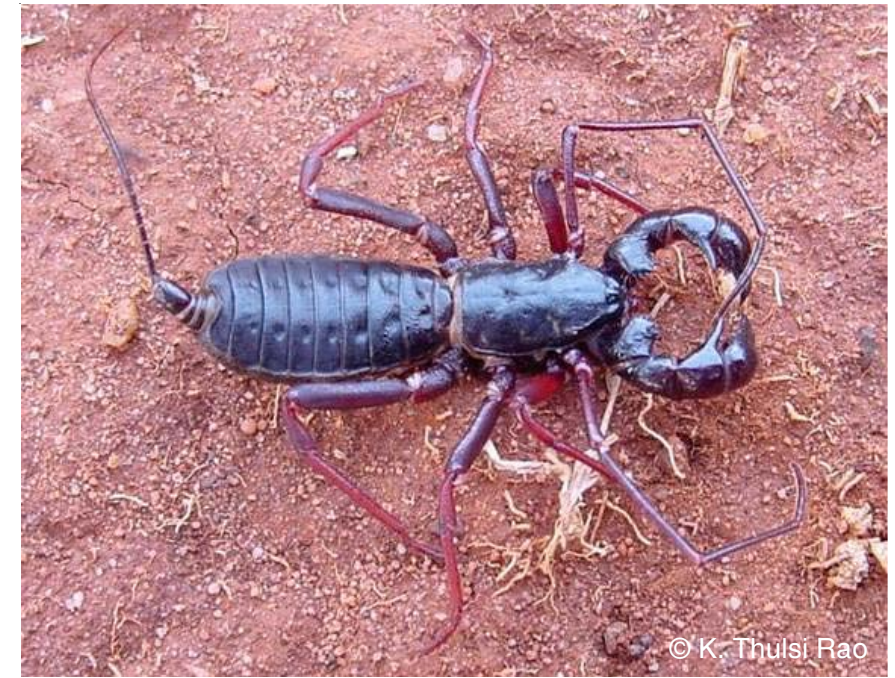

Image 2. Thelyphonus sepiaris (Butler 1873) in life

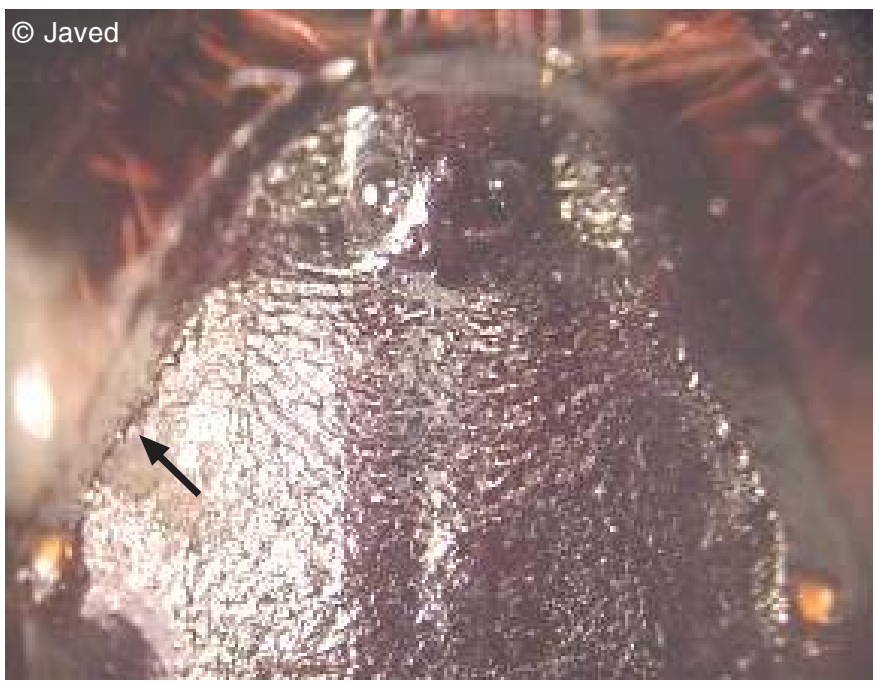

Image 3. Dorsal view of thorax-anterior region (arrow pointing towards a ocular keel)

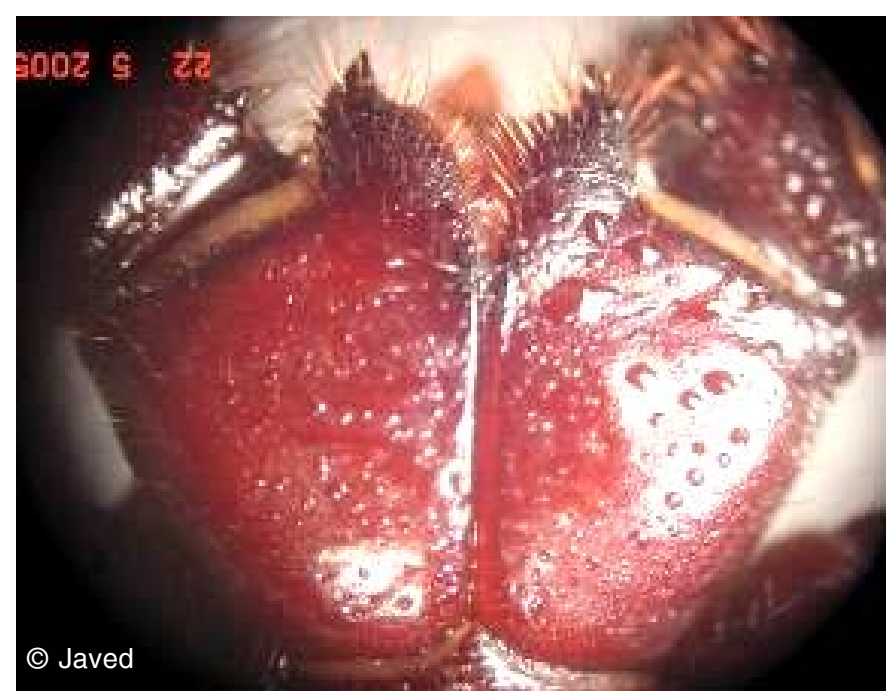

Image 5. Ventral view of pedipalp coxa showing maxillary process with tooth. 


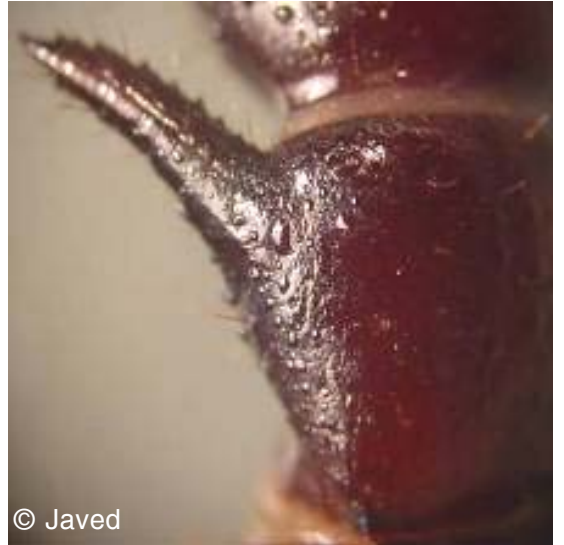

Image 6. Dorsal view of patella of right pedipalp showing patellar apophysis

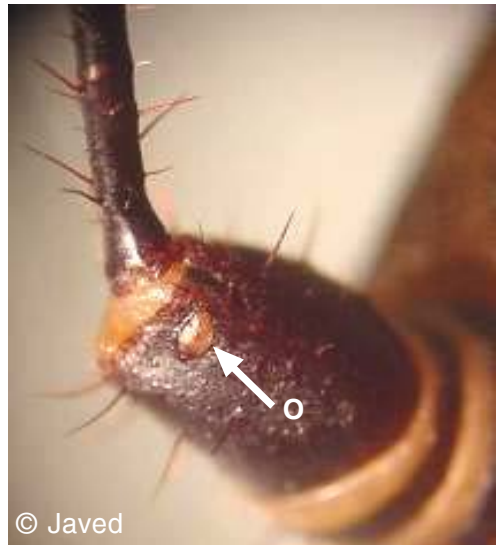

Image 7. Lateral view of anal segment showing ommatoid (O)

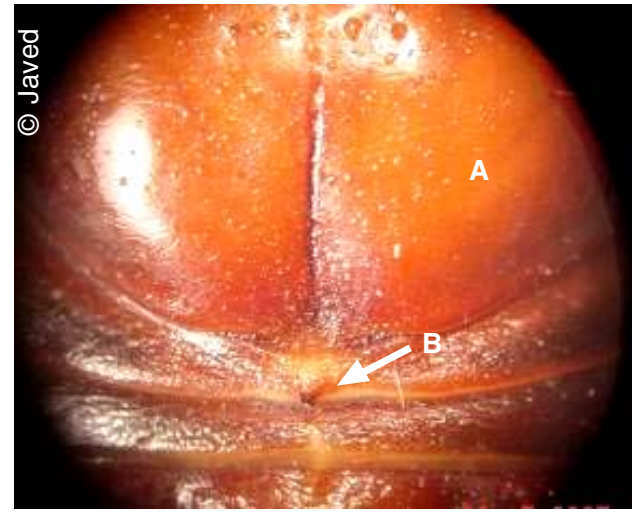

Image 8. Ventral view of anterior abdomen of male showing first sternum (A) and tooth on second sternum (B). (including metatarsus) length 4.50. Leg III: femur length 8.50, patella length 3.50 , tibia length 5.50 , (including metatarsus) length 4.50. Leg IV: femur length 11.00, patella length 4.50, tibia length 10.50, (including metatarsus) length 6.00. Caudal flagellum length 37.00 .

Habits and Habitats: All the specimens encountered were found under either decaying logs or stones near humid places full of leaf litter near perennial water source. Microhabitat characteristics of all the places from where the species was sighted were similar. The general habitat of these localities is typical southern tropical dry deciduous and southern tropical moist deciduous forest types intermingled with scrub. Generally Whip-scorpions are found near damp places beneath stones or pieces of wood, in the crannies of rocks or of termite mounds or other crevices where shelter from light and protection from the rays of the sun are obtained. Some of them are known to excavate burrows for protection of their young. The female carries the egg mass encased in a glutinous membrane attached to the lower side of the abdomen (Pocock 1900).

Known Distribution: Madras (now Chennai), Tamil Nadu, India; Jaffna and Trincomalee, Sri Lanka (Pocock 1900).

Status: Thelyphonus sepiaris (Butler 1873) is endemic to Deccan in Oriental region. The present report extends its range further northern and inland in to the Eastern Ghats and Godavari River basin in Andhra Pradesh, again in Deccan plateau.

Remarks: On the basis of the known distribution, this is the first ever record of this species from Andhra Pradesh, India.

\section{References}

Eisner, T., J. Meinwald, A. Monro \& R. Ghent (1961). Defense mechanisms of Arthropods I. The composition and function of the spray of the whipscorpion, Mastigoproctus giganteus (Lucas) (Arachnida Pedipalpida). Journal of Insect Phisiology 6: 272-298.

Harvey, M.S. (2002). The neglected cousins: What do we know about the smaller arachnid orders?. The Journal of Arachnology 30: 357372 .

Harvey, M.S. (2003). Catalogue of the Smaller Arachnid Orders of the World. CSIRO Publishing, Victoria, Australia, 385pp.

Pocock, R.I. (1900). Fauna of British India, Arachnida. Taylor and Francis, London, 279pp.

Rowland, J.M. \& J.A.L. Cooke (1973). Systematics of the arachnid order Uropygida (Thelyphonida). The Journal of Arachnology 1: 5571 . 